\title{
Global Switches and Fine-Tuning-ABA Modulates Plant Pathogen Defense
}

\author{
Bob Asselbergh, ${ }^{1,2}$ David De Vleesschauwer, ${ }^{1}$ and Monica Höfte ${ }^{1}$ \\ ${ }^{1}$ Laboratory of Phytopathology, Ghent University, 9000 Gent, Belgium; ${ }^{2}$ VIB Department of Plant Systems Biology, \\ 9052 Zwijnaarde, Belgium
}

Submitted 13 November 2007. Accepted 8 February 2008.

Plants are obliged to defend themselves against a wide range of biotic and abiotic stresses. Complex regulatory signaling networks mount an appropriate defense response depending on the type of stress that is perceived. In response to abiotic stresses such as drought, cold, and salinity, the function of abscisic acid (ABA) is well documented: elevation of plant ABA levels and activation of ABA-responsive signaling result in regulation of stomatal aperture and expression of stress-responsive genes. In response to pathogens, the role of $\mathrm{ABA}$ is more obscure and is a research topic that has long been overlooked. This article aims to evaluate and review the reported modes of $\mathrm{ABA}$ action on pathogen defense and highlight recent advances in deciphering the complex role of $\mathrm{ABA}$ in plant-pathogen interactions. The proposed mechanisms responsible for positive or negative effects of $\mathrm{ABA}$ on pathogen defense are discussed, as well as the regulation of $\mathrm{ABA}$ signaling and in planta ABA concentrations by beneficial and pathogenic microorganisms. In addition, the fast-growing number of reports that characterize antagonistic and synergistic interactions between abiotic and biotic stress responses point to ABA as an essential component in integrating and finetuning abiotic and biotic stress-response signaling networks.

Additional keywords: callose, ethylene, salicylic acid.

The capacity of plants to cope with the constant threat of a variety of plant pathogens demonstrates the efficiency of their defensive machinery. Plants possess preformed physical and biochemical barriers. When these constitutive defenses are overcome by a pathogen, recognition leads to a complex signaling cascade of inducible defense responses. The phytohormones, salicylic acid (SA), jasmonate (JA), and ethylene (ET) were shown to modulate these signaling pathways. Instead of forming isolated hormonally controlled signaling cascades, complex regulatory signaling networks with frequent crosstalk mount an appropriate defense response depending on the type of pathogenic stimuli that is present (Glazebrook 2005; Lorenzo and Solano 2005; Thomma et al. 2001; van Loon et al. 2006). Furthermore, there is frequent cross-talk between the signaling networks controlling the responses to abiotic stresses (Fujita et al. 2006; Mauch-Mani and Mauch 2005). The use of shared components in biotic and abiotic stress responses is rationalized by economical use of biochemical resources,

Corresponding author: Monica Höfte; Telephone: +32 926460 17; Fax: +32926462 38; E-mail: monica.hofte@UGent.be whereas antagonistic relationships between different stress responses result from the plants' need to activate an appropriate response to the type of stress that is encountered.

The phytohormone abscisic acid (ABA) not only regulates plant developmental processes such as seed maturation, dormancy, inhibition of germination, photoregulation, inhibition of lateral root formation, senescence, and flowering inhibition but also has a primary function in response to salt, drought, and osmotic and cold stress (Finkelstein and Rock 2002; Finkelstein et al. 2002). In addition to this well-studied function in the response to abiotic stress, a fast-growing number of studies have demonstrated that ABA also is involved prominently in the response to pathogens and is implicated in the integration of different stress-response signaling networks. However, to date, our knowledge regarding the functions of ABA in response to pathogens is still very fragmentary. ABA was reported to play an ambivalent role in pathogen defense and several putative mechanisms were proposed (Mauch-Mani and Mauch 2005). This article aims to evaluate and review the reported modes of ABA action on pathogen defense and highlight recent advances in deciphering the complex role of $\mathrm{ABA}$ in plant-pathogen interactions.

\section{Mechanisms involved in the modulation of disease resistance by $\mathrm{ABA}$.}

Mounting evidence suggests that ABA plays an ambivalent role in defense responses to pathogens, acting as both a positive and negative regulator of disease resistance by interfering at multiple levels with biotic stress signaling. In this context, a wide range of putative mechanisms underpinning the beneficial and detrimental effects of ABA on plant defense have been proposed, including the suppression of SA- and ET/JA-dependent basal defenses, synergistic cross-talk with JA signaling, suppression of reactive oxygen species (ROS) generation, induction of stomatal closure, and stimulation of callose deposition. A comprehensive overview of the effects of ABA in various plant-pathogen interactions is provided in Table 1, and the proposed modes of ABA action will be discussed in this section. Generally, the outcome of alterations in ABA content or ABA signaling seems independent of the pathogen lifestyle or mode of pathogen attack, because ABA can influence resistance against both necrotrophs and biotrophs positively and negatively. Furthermore, differences in plant species used in the various experimental systems can account only in part for the diverse effects of $\mathrm{ABA}$ on resistance. For example, in tomato, ABA is associated predominantly with susceptibility but, in Arabidopsis, both negative and positive effects on resistance were reported. Moreover, the conflicting results cannot be com- 
pletely reconciled by assuming that the role of ABA is plantpathogen interaction specific because, within the same interaction, several modes of action of ABA with divergent effects on disease resistance might be involved at different stages of infection. For instance, in Arabidopsis, ABA-regulated stomatal closure is a key element of preinvasion SA-regulated innate immunity to Pseudomonas syringae (Melotto et al. 2006), whereas post-penetration virulence of the same pathogen depends on ABA-mediated suppression of several basal defense responses (de Torres-Zabala et al. 2007; Mohr and Cahill 2003, 2007). These results demonstrate that the timing of infection is also a crucial element in the regulatory role of ABA on pathogen defense.

Suppression of phenylalanine ammonia lyase activity, secondary metabolites, and SA accumulation. A possible mechanism that can explain the negative impact of ABA on pathogen defense is the suppression of phenylalanine ammonia lyase (PAL) activity by basal or elevated ABA levels (Audenaert et al. 2002; McDonald and Cahill 1999; Ward et al. 1989). PAL is a key enzyme in the early steps of the phenylpropanoid biosynthetic pathway, leading to the production of secondary antimicrobial metabolites, including phytoalexins and phytoanticipins. Incompatible interactions between soybean and Phytophthora sojae were marked by a sharp increase in PAL activity within $4 \mathrm{~h}$ postinoculation, which was not present in compatible interactions and could be suppressed by exogenous ABA application (McDonald and Cahill 1999). In contrast, artificial reduction of ABA levels with norflurazon during inoculation with compatible isolates elevated PAL activity and led to the formation of incompatible lesions (McDonald and Cahill 1999). It was shown earlier in the same plant pathosystem that ABA suppresses PAL activity at the transcriptional level (Ward et al. 1989). Furthermore, resistance in this interaction was correlated with the accumulation of the phenylpropanoid-derived compound glyceollin, which could be suppressed by ABA treatment, and was not correlated with lignin deposition or with the expression of a hypersensitive response (HR) (Mohr and Cahill 2001). These data show that plant ABA levels can determine the outcome of a plantpathogen interaction by controlling the accumulation of phytoalexin production through regulation of phenylpropanoid biosynthesis.

Table 1. Effects of abscisic acid (ABA) on plant-pathogen interactions and proposed mode of ABA action ${ }^{\mathrm{a}}$

\begin{tabular}{|c|c|c|c|c|c|c|c|c|c|}
\hline \multirow[b]{3}{*}{ Host plant } & \multirow[b]{3}{*}{ Pathogen } & \multirow[b]{3}{*}{ Mode of action ${ }^{\mathbf{b}}$} & \multicolumn{6}{|c|}{ Method and effect on resistance } & \multirow[b]{3}{*}{ Reference } \\
\hline & & & \multicolumn{2}{|c|}{$\begin{array}{c}\text { ABA } \\
\text { decrease }\end{array}$} & \multicolumn{2}{|c|}{$\begin{array}{c}\text { Inactivation of } \mathrm{ABA} \\
\text { signaling }\end{array}$} & \multicolumn{2}{|c|}{$\begin{array}{c}\text { ABA } \\
\text { increase }\end{array}$} & \\
\hline & & & Method & Effect & Method & Effect & Method & Effect & \\
\hline Arabidopsis & Pseudomonas syringae & $\begin{array}{l}\text { Suppression of basal } \\
\text { defense responses }\end{array}$ & bm: aao3 & ++ & $\begin{array}{l}\text { im: abil-1, abi2-1, } \\
\text { 35S::HAB1 }\end{array}$ & ++ & ex & - & $\begin{array}{l}\text { de Torres-Zabala et al. } \\
2007\end{array}$ \\
\hline Arabidopsis & Pseudomonas syringae & $\begin{array}{l}\text { Suppression of SA } \\
\text { responses and lignin } \\
\text { accumulation }\end{array}$ & bm: abal-1 & $=$ & im: abil-1 & $=$ & ex, ds & -- & $\begin{array}{l}\text { Mohr and Cahill 2003, } \\
2007\end{array}$ \\
\hline Arabidopsis & Pseudomonas syringae & $\begin{array}{l}\text { Stomatal closure in } \\
\text { innate immunity } \\
\text { pathway }\end{array}$ & bm: aba3-1 & -- & gcsm: coil $1-20$, ost $1-2$ & & ex & + & Melotto et al. 2006 \\
\hline Arabidopsis & Alternaria brassicicola & $\begin{array}{l}\text { Stimulation of JA } \\
\text { biosynthesis }\end{array}$ & $\begin{array}{l}\mathrm{bm}: \text { aao } 3-2, \\
\text { aba2-12 }\end{array}$ & -- & im: abi4-1 & -- & ND & & Adie et al. 2007 \\
\hline Arabidopsis & Alternaria brassicicola & $\begin{array}{l}\text { Priming for callose } \\
\text { deposition }\end{array}$ & bm: abal-5 & - & im: $a b i 4-1$ & - & ex & + & $\begin{array}{l}\text { Ton and Mauch-Mani, } \\
2004\end{array}$ \\
\hline Arabidopsis & $\begin{array}{l}\text { Plectosphaerella } \\
\text { cucumerina }\end{array}$ & $\begin{array}{l}\text { Priming for callose } \\
\text { deposition }\end{array}$ & bm: abal-5 & $=$ & im: abi4-1 & $=$ & ex & + & $\begin{array}{l}\text { Ton and Mauch-Mani, } \\
2004\end{array}$ \\
\hline Arabidopsis & $\begin{array}{l}\text { Plectosphaerella } \\
\text { cucumerina }\end{array}$ & ND & bm: abal-6 & ++ & im: abi1-1, abi2-1 & ++ & ND & ND & $\begin{array}{l}\text { Hernández-Blanco et al. } \\
2007\end{array}$ \\
\hline Arabidopsis & Sclerotinia sclerotiorum & Stomatal closure & bm: $a b a 2-1$ & -- & $\begin{array}{c}\text { im: abil-1(-), abi2- } \\
\quad 1(=), \text { abi3-l(-) }\end{array}$ & $-1=$ & ND & ND & $\begin{array}{l}\text { Guimarães and } \\
\text { Stotz,2004 }\end{array}$ \\
\hline Arabidopsis & Ralstonia solanacearum & $\begin{array}{l}\text { Signaling in irx-mediated } \\
\text { resistance (leading to } \\
\text { antimicrobial } \\
\text { compounds) }\end{array}$ & bm: abal-6 & -- & im: abil-1, abi2-1 & -- & ND & ND & $\begin{array}{l}\text { Hernández-Blanco et al. } \\
2007\end{array}$ \\
\hline Arabidopsis & Leptosphaeria maculans & $\begin{array}{l}\text { Signaling in RLM path- } \\
\text { way leading to callose- } \\
\text { dependent and -inde- } \\
\text { pendent resistance }\end{array}$ & $\begin{array}{l}\text { bm: aba1-3, } \\
\text { aba2-1, } \\
\text { aba3-1 }\end{array}$ & - & $\begin{array}{l}\text { im: abil-1(-), } \\
\text { abi4-1(--), abi2- } \\
\text { l(=), abi3-l(-), abi5- } \\
l(=)\end{array}$ & $-1--1=$ & ex & $=$ & Kaliff et al. 2007 \\
\hline Arabidopsis & Fusarium oxysporum & $\begin{array}{l}\text { Suppression of JA/ET } \\
\text { responses }\end{array}$ & bm: $a b a 2-1$ & + & ND & ND & ND & ND & Anderson et al. 2004 \\
\hline Arabidopsis & $\begin{array}{l}\text { Hyaloperonospora } \\
\text { parasitica }\end{array}$ & ND & bm: abal-1 & ++ & im: $a b i 1-1$ & $=$ & ex, ds & $=$ & Mohr and Cahill 2003 \\
\hline Arabidopsis & Pythium irregulare & $\begin{array}{l}\text { Stimulation of JA } \\
\text { biosynthesis }\end{array}$ & $\begin{array}{l}\text { bm: aao3-2, } \\
\text { aba2-12 }\end{array}$ & -- & im: abi4-1 & -- & ND & ND & Adie et al. 2007 \\
\hline Arabidopsis & Botrytis cinerea & ND & $\begin{array}{l}\text { bm: } a a o 3-2, \\
\text { aba2-12 }\end{array}$ & ++ & im: $a b i 4-1$ & + & ND & ND & Adie et al. 2007 \\
\hline Tomato & Botrytis cinerea & $\begin{array}{l}\text { Suppression of SA re- } \\
\text { sponses, PAL activity, } \\
\text { hydrogen peroxide } \\
\text { accumulation and cell } \\
\text { wall fortification }\end{array}$ & $\begin{array}{l}\text { bm: sitiens, } \\
\text { notabilis, } \\
\text { flacca; bi: } \\
\text { fluridone }\end{array}$ & ++ & ND & ND & ex, ss, ds & - & $\begin{array}{l}\text { Audenaert et al. 2002; } \\
\text { Asselbergh et al. 2007; } \\
\text { Achuo et al. } 2006\end{array}$ \\
\hline
\end{tabular}

\footnotetext{
a ND: not determined; =: no significant effect; +: moderate positive effects; ++: relatively strong positive effects; -: moderate negative effects; - -: relatively strong negative effects on disease resistance, based on the authors' evaluation of disease indexes in each report; bm: biosynthesis mutants; bi: biosynthesis inhibition; im: insensitive mutants; gcsm: guard cell signaling mutants; ex: exogenous application; ds: drought stress; cs: cold stress; ss: salt stress; os: osmotic stress; ps: proton stress.
}

b Proposed mode of ABA action on defense responses. SA: salicylic acid; JA: jasmonate; ET: ethylene. 
Besides leading to the formation of antimicrobial secondary metabolites, the phenylpropanoid pathway is involved in the synthesis of the plant defense hormone SA. In Arabidopsis, gene-for-gene resistance to Pseudomonas syringae is SA dependent and application of exogenous ABA prevents the accumulation of SA and suppresses resistance (Mohr and Cahill 2007). Transcriptome analysis confirmed the ABA-mediated suppression of genes in the early steps of the phenylpropanoid pathway, including PAL and 4-coumarate/CoA ligase (Mohr and Cahill 2007). In tomato, it was shown that the ABA-deficient sitiens mutant is hypersensitive to the SA analog benzothiadiazole and displays a hyperinduction of PAL activity after pathogen attack (Audenaert et al. 2002). Comparison of the transcriptome of sitiens and wild-type tomato confirmed transcriptional activation of the phenylpropanoid biosynthetic pathway in sitiens, and also showed an increased accumulation of SA-inducible defense-related transcripts such as PR1 both prior to and quickly after inoculation with Botrytis cinerea (Asselbergh et al. 2007). A higher basal PR1 mRNA accumulation also was detected in other ABA-deficient tomato mutants (Thaler and Bostock 2004). In addition, downregulation of $\beta$-1,3-glucanase transcripts, another SA-inducible pathogenesis-related (PR) protein (PR2), was detected in tobacco cell cultures treated with ABA (Rezzonico et al. 1998). Together, these results indicate that exogenous ABA application can suppress SA accumulation and SA-inducible defense transcript accumulation, whereas a decrease in endogenous ABA results in constitutive activation and hyperinduction of SA-dependent defenses.

In addition to the repression of phenylpropanoid biosynthesis, other mechanisms were suggested for the suppressive effect of ABA on SA-inducible gene expression. Adie and associates (2007) proposed that ABA-SA antagonism also could be explained by an indirect effect based on the ABA-mediated induction of JA biosynthesis. Another conceivable justification for ABA-SA antagonism lies in the positive effect of ABA on callose formation. Callose was shown to block SA-inducible defense responses (Nishimura et al. 2003); therefore, the action of ABA on SA-dependent responses could be partly due to enhancement of callose deposition. Both of these hypotheses are discussed later.

Suppression of ROS accumulation. The importance of ROS accumulation during pathogen defense is well documented (Apel and Hirt 2004; Lamb and Dixon 1997; Torres and Dangl 2005; Wojtaszek 1997). Analysis of the resistance mechanisms of the ABA-deficient sitiens tomato mutant revealed the importance of rapid and extensive hydrogen peroxide accumulation in arresting the necrotrophic pathogens $B$. cinerea and $E r$ winia chrysanthemi (Asselbergh et al. 2007, 2008). Extracellular hydrogen peroxide accumulation and activation of peroxidases in sitiens caused rapid cell wall modification upon

Table 1. Continued from preceding page

\begin{tabular}{|c|c|c|c|c|c|c|c|c|c|c|}
\hline \multirow[b]{3}{*}{ Host plant } & \multirow[b]{3}{*}{ Pathogen } & \multirow[b]{3}{*}{ Mode of action ${ }^{b}$} & \multicolumn{7}{|c|}{ Method and effect on resistance } & \multirow[b]{3}{*}{ Reference } \\
\hline & & & \multicolumn{2}{|c|}{$\begin{array}{c}\text { ABA } \\
\text { decrease }\end{array}$} & \multicolumn{3}{|c|}{$\begin{array}{c}\text { Inactivation of } \mathbf{A B A} \\
\text { signaling }\end{array}$} & \multicolumn{2}{|c|}{$\begin{array}{c}\text { ABA } \\
\text { increase }\end{array}$} & \\
\hline & & & Method & Effect & & Method & Effect & Method & Effect & \\
\hline Tomato & Erwinia chrysanthemi & $\begin{array}{l}\text { Suppression of ROS } \\
\text { accumulation and cell } \\
\text { wall fortification }\end{array}$ & bm: sitiens & ++ & ND & & ND & ex & -- & Asselbergh et al. 2008 \\
\hline Tomato & Oidum neolycopersici & ND & bm: sitiens & + & ND & & ND & ex & $=$ & Achuo et al. 2006 \\
\hline Tomato & Pseudomonas syringae & $\begin{array}{l}\text { Suppression of SA } \\
\text { responses }\end{array}$ & $\begin{array}{l}\text { bm: sitiens, } \\
\text { flacca }\end{array}$ & + & ND & & ND & ss & - & Thaler and Bostock 2004 \\
\hline Tomato & Sclerotinia sclerotiorum & ND & bm: sitiens & ++ & ND & & ND & ND & ND & $\begin{array}{c}\text { Asselbergh and Höfte, } \\
\text { unpublished results }\end{array}$ \\
\hline Tobacco & Peronospora tabacina & ND & ND & ND & ex & & -- & & & Salt et al. 1986 \\
\hline Tobacco & Ralstonia solanacearum & ND & ND & ND & ex & & - & & & $\begin{array}{l}\text { Steadman and Sequira } \\
1970\end{array}$ \\
\hline Tobacco & Tobacco mosaic virus & $\begin{array}{l}\text { Stimulation of callose } \\
\text { deposition }\end{array}$ & ND & $\mathrm{ND}$ & ND & & ND & ex & + & $\begin{array}{l}\text { Whenham et al. 1986; } \\
\text { Fraser and Whenham } \\
\text { 1989; Balazs et al. } \\
\text { 1973; Rezzonico et al. } \\
\text { 1998 }\end{array}$ \\
\hline Barley & $\begin{array}{l}\text { Erysiphe graminis } \\
\text { f. sp. hordei }\end{array}$ & ND & ND & ND & ex & & -- & & & Edwards 1983 \\
\hline Barley & $\begin{array}{l}\text { Blumeria graminis } \\
\text { f. sp. hordei }\end{array}$ & ND & ND & ND & ND & & ND & ex, os, ps & + & Wiese et al. 2004 \\
\hline Potato & Phytophthora infestans & Unknown & ND & ND & ND & & ND & ex & -- & Henfling et al. 1980 \\
\hline Potato & $\begin{array}{l}\text { Cladosporium } \\
\text { cucumerinum }\end{array}$ & ND & ND & ND & ND & & ND & ex & -- & Henfling et al. 1980 \\
\hline Rice & Magnaporthe grisea & $\begin{array}{l}\text { Suppression of whole- } \\
\text { plant-specific } \\
\text { resistance }\end{array}$ & bi: fluridone & + & ND & & ND & ex, cs & - & Koga et al. 2004 \\
\hline Rice & Bipolaris oryzae & $\begin{array}{l}\text { Priming for MPK5- } \\
\text { mediated repression of } \\
\text { ethylene signaling }\end{array}$ & bi: fluridone & $=$ & ND & & ND & ex & + & $\begin{array}{l}\text { De Vleesschauwer and } \\
\text { Höfte, unpublished } \\
\text { results }\end{array}$ \\
\hline Bean & $\begin{array}{l}\text { Colletotrichum } \\
\text { lindemuthianum }\end{array}$ & ND & bi: fluridone & - & ND & & ND & ex & + & Dunn et al. 1990 \\
\hline Lily & Botrytis elliptica & $\begin{array}{l}\text { Stomatal closure in } \\
\text { probenazol-induced } \\
\text { resistance }\end{array}$ & ND & ND & ND & & ND & ex & + & Lu et al. 2007 \\
\hline Wheat & $\begin{array}{l}\text { Erysiphe graminis } \\
\text { f. sp. tritici }\end{array}$ & ND & ND & ND & ND & & ND & ND & ND & Nikitina and Talieva 2001 \\
\hline Soybean & Phytophthora sojae & $\begin{array}{l}\text { Suppression of PAL } \\
\text { activity, glyceollin } \\
\text { accumulation }\end{array}$ & bi: norflurazon & ++ & ND & & ND & ex & -- & $\begin{array}{l}\text { Ward et al., 1989; } \\
\text { McDonald and Cahill } \\
\text { 1999; Mohr and Cahill } \\
2001\end{array}$ \\
\hline
\end{tabular}


pathogen inoculation by protein cross-linking and incorporation of phenolic compounds, causing the arrest of pathogen progression. Pathogen susceptibility could be restored by application of exogenous ABA or by pharmacologic disruption or removal of hydrogen peroxide accumulation (Asselbergh et al. 2007). Extensive ROS accumulation and increases in peroxidase activity as a result of ABA deficiency is consistent with the hyperinduction of SA-inducible defenses in ABA mutants (Asselbergh et al. 2007; Audenaert et al. 2002). Many studies report on the relationship between ROS and SA in biotic stress responses. It is believed that ROS and SA work together in a self-amplifying system in establishing systemic acquired resistance (Alvarez et al. 1998; Durrant and Dong 2004; Van Breusegem et al. 2001; Van Camp et al. 1998). This model is corroborated by ABA deficiency-triggered potentiation of both ROS- and SA-mediated defense. On the other hand, ROS are important messengers in ABA-mediated stress responses. ROS are key signals in regulating stress-adaptive ABA responses (Pastori and Foyer 2002) and ABA signaling in guard cells requires ROS formation to interact with $\mathrm{Ca}$ channels to induce stomatal closure (Kwak et al. 2006; Li et al. 2006). Interestingly, guard cell ABA activates ROS-generating NADPH oxidases (Kwak et al. 2006), which are also necessary for ROS production during pathogen defense (Torres and Dangl 2005). Furthermore, ROS production resulting in stomatal closure could be induced by application of plant cell wall degradation products (oligogalacturonides) (Lee et al. 1999), and it was shown that hydrogen peroxide-dependent defense responses in sitiens most likely also are elicited by oligogalacturonides (Asselbergh et al. 2008). Together, it seems that at least some components of ROS generation and ROSsignaling activation are common for ABA-responsive abiotic stress signaling in guard cells and for hyperactivation of pathogen defense in ABA-deficient plants. At present, the mechanism by which ABA-deficiency in sitiens leads to rapid extensive ROS formation upon pathogen attack is conjectural.

$A B A$ effect on JA/ET-responsive defenses. The antagonistic effect of ABA on JA/ET pathogen defense signaling was proposed as an alternative mechanism for ABA to negatively influence pathogen defense (Anderson et al. 2004; MauchMani and Mauch 2005). By using PDF1.2, CHI, and HEL transcript accumulation as markers for JA/ET-responsive gene expression in Arabidopsis, it was shown that both basal and JA/ET-induced defense gene expression was suppressed by exogenous ABA and was upregulated in ABA-deficient abal and aba 2 mutants, the latter resulting in increased resistance to Fusarium oxysporum (Anderson et al. 2004).

During wound and pathogen stress, positive and negative interactions between JA and ET signaling pathways are essential for the establishment of suitable plant defense responses. During pathogen attack, ET and JA cooperate through transcriptional induction of ET response factor 1 (ERF1), which results in activation of pathogen response genes such as PDF 1.2, CHI, and HEL. In response to wounding, JA activates the transcription factor AtMYC2, leading to wound stress-specific gene activation (such as VSP and lox). Repression of pathogen response genes by AtMYC2 and repression of wound response genes by ERF1 constitute important points of cross-talk between the two signaling pathways (Lorenzo and Solano 2005). AtMYC2 expression was shown to be activated by ABA (Lorenzo et al. 2004) and it was suggested that ABA precedes JA in the activation of AtMYC2-mediated wound responses (Lorenzo and Solano 2005). Therefore, AtMYC2 functions as a mediator of ABA to repress JA/ET-induced pathogen response (Anderson et al. 2004). However, the suppression of JA/ET-induced pathogen response genes by ABA cannot be attributed solely to AtMYC2, because a suppressive effect remained in an Atmyc2-negative mutant background (Anderson et al. 2004). Antagonistic interactions between ET and ABA signaling form an alternative mechanism of ABA to repress the JA/ET-induced pathogen response. For example, it was shown that ET treatment quickly induces activation of $\mathrm{ABI} 1$ and $\mathrm{ABI} 2$, two negative regulators of ABA signaling (De Paepe et al. 2004). Furthermore, by using ABA and ET signaling mutants, it was shown that the relationship between the two phytohormones is mutually antagonistic in vegetative tissues (Anderson et al. 2004).

Recent evidence suggests that the antagonistic ABA-ET crosstalk might be modulated by the ET-responsive element binding factor AtERF4 (Yang et al. 2005). AtERF4 is a transcriptional repressor whose expression is induced by ABA, ET, or JA exogenous treatment, while its overexpression leads to the inhibition of GCC box-containing defense genes, ET insensitivity, and decreased ABA sensitivity. In rice, exogenous ABA treatment has been shown to decrease endogenous ET levels and, consequently, increase host susceptibility to Magnaporthe oryzae (Yang 2007). Elegant research by Yinong Yang's group revealed that the suppressive effect of ABA on the ET signaling pathway is mediated by the OsMPK5 gene. OsMPK5 encodes an ABA-inducible mitogen-activated protein kinase that positively regulates endogenous ABA level and abiotic stress tolerance but negatively modulates endogenous ET level, PR gene expression, and resistance to $M$. oryzae (Xiong and Yang 2003; Yang 2007).

Although antagonistic interactions between JA and ABA have been reported (Lorenzo and Solano 2005; Moons et al. 1997), these two hormones often act as positive regulators in the same signaling pathway. In Arabidopsis guard cells, both JA and ABA induce stomatal closure by activation of identical secondary messengers, such as ROS, NO, $\mathrm{Ca}^{2+}$ permeable cation channels, and S-type anion channels (Munemasa et al. 2007). Recently, Adie and associates (2007) demonstrated that ABA is an essential signal leading to JA biosynthesis, with resultant activation of defense responses against the damping-off oomycete Pythium irregulare. Defense signaling against this pathogen relies partly on ET and SA but is predominantly mediated by JA, with JAinsensitive coil mutants showing extreme susceptibility. Transcriptome analysis of wild-type, ET-, SA-, and JA-related mutants (Col0, ein2-5, sid2-1, and coil-1, respectively) after infection with $P$. irregulare allowed the division in JA-, ET-, and SAdependent and JA-, ET-, and SA-independent genes induced by P. irregulare. $P$. irregulare-induced JA-, ET-, and SA-dependent genes were dominated by JA-responsive genes. Meta-analysis confirmed the dependence on JA-responsive genes as well as revealed high similarity of the $P$. irregulare-induced transcriptome with the response to ABA. Promoter analysis of the JA-, ET-, and SA-dependent $P$. irregulare-induced genes also revealed an overrepresentation of ABA response elements. Furthermore, the $P$. irregulare-induced transcriptome independent of JA, ET, and SA clustered together with the profiles of responses to ABA and abiotic stresses. ABA-deficient (aba2-12) and ABA-insensitive (abi4-1) mutants showed impaired JA biosynthesis and increased susceptibility upon $P$. irregulare infection (Adie et al. 2007). Together, these results elegantly show the requirement for ABA signaling to activate JA-dependent resistance to $P$. irregulare. Interestingly, this study also confirmed the downregulation by ABA of a group of JA/ET-responsive genes, such as $P D F 1-2, H E L$, and $b-C H I$, which confirmed earlier findings (Anderson et al. 2004). However, the transcriptomic view showed that the major effect of ABA is the opposite, activating many ABA-specific and ABA- or JA-related defense genes (Adie et al. 2007).

Collectively, it appears that the cross-talk of ABA with JA and ET signaling pathways occurs at multiple convergence 
points with opposite effects on disease resistance. On the one hand, ABA acts negatively on the specific set of pathogen response genes that are controlled synergistically by ET and JA, leading to enhanced disease susceptibility. On the other hand, ABA positively affects JA biosynthesis in the activation of defense responses against the oomycete $P$. irregulare.

Stomatal closure. When effects of ABA on disease resistance are evaluated, special care should be taken to discriminate between direct and indirect effects on pathogen defense, especially during interactions with root rot or wilting pathogens. Because these types of pathogens impinge plant water balances or fluxes and cause severe dehydration stress, ABAinduced abiotic stress responses to enhance dehydration stress tolerance will be activated and, thereby, can reduce disease symptoms. ABA-induced stomatal closure to limit evaporation water loss and to counteract wilting symptoms is a nice example of an indirect positive effect of ABA on pathogen defenses, because it is principally an abiotic stress response and not a response to biotic stress.

In addition to these indirect effects, a biologically very relevant direct positive effect of ABA signaling on pathogen defense is by closing stomata to prevent pathogen invasion. It was shown recently that stomatal closure is integral to preinvasion pathogen-associated molecular pattern (PAMP)-induced innate immunity to bacteria (Melotto et al. 2006; Underwood et al. 2007). Stomata close upon recognition of plant pathogens, human pathogens (plant nonpathogens), and isolated PAMP molecules, a process that requires ABA signaling in guard cells and ABA biosynthesis (Melotto et al. 2006). Moreover, it was elegantly demonstrated that Pseudomonas syringae pv. tomato needed the virulence factor coronatine in order to enter internal leaf tissue by inhibiting ABA-induced stomatal closure. Coronatine, a JA mimic, counteracts PAMP-induced stomatal closure downstream of ABA but requires functional COI1 signaling. Interestingly, PAMP-induced stomatal closure was compromised in SA-deficient transgenic nahG plants and SAbiosynthetic mutant eds16-2 plants, indicating that defense through stomatal closure is an integral part of the SA-regulated innate immune system (Melotto et al. 2006). These results show that counteracting ABA-dependent signaling in guard cells is a pathogenic strategy to overcome preinvasion SAregulated innate immunity. This is in sharp contrast to the upregulation of ABA signaling and ABA biosynthesis needed for post-penetration virulence (de Torres-Zabala et al. 2007) and the repression of SA accumulation and SA-dependent defense gene expression by ABA during infection (Mohr and Cahill 2007), both in the same plant pathosystem. Interestingly, stomatal defense and bacterial suppression of stomatal defense seem to be common phenomena in plant-bacterium interactions, because PAMPs also induce stomatal closure in tomato, which also could be modulated by $P$. syringae pv. tomato (Melotto et al. 2006). Considering that, in natural environments, bacterial and many fungal pathogens rely entirely on accidental wounds or natural plant openings such as stomata to enter internal plant tissues, the impact of stomatal defense on plant-pathogen interactions in nature can hardly be overestimated. It remains to be elucidated whether PAMPinduced ABA-signaling is limited to guard cells or whether ABA-induced signaling early upon pathogen recognition also occurs in other plant cell types.

In addition, it was shown earlier that the fungal toxin fusicoccin promotes stomatal opening and antagonizes ABA-induced stomatal closure (Marré 1979). Also, the fungal necrotrophic pathogen Sclerotinia sclerotiorum uses the virulence factor oxalate to prevent ABA-induced stomatal closure during infection (Guimarães and Stotz 2004). Increased wilting and facilitation of hyphal emergence and secondary colonization were proposed to result from the prevention of stomatal closure. The mechanism by which oxalate suppresses ABA-induced stomatal closure remains unknown (Guimarães and Stotz 2004), and the elucidation of this mechanism will be complicated further by the multiple functions of oxalate in necrotrophic virulence (Van Kan 2006). Nevertheless, ABA-induced stomatal closure is undoubtedly an important plant defense strategy towards pathogens.

Stimulation of callose deposition. Another positive effect of ABA on pathogen defense is its ability to stimulate callose deposition. Callose is a $\beta$-1,3-glucan that is deposited in cell wall appositions (papillae) that can block pathogen entry (Aist 1976). It was reported that both ABA signaling and callose formation are prerequisites for $\beta$-amino butyric acid (BABA)triggered induced resistance to Plectosphaerella cucumerina and Alternaria brassicicola in Arabidopsis (Ton and MauchMani 2004). Treatment with exogenous ABA could mimic the effect of BABA and resulted in priming for callose and resistance to $P$. cucumerina. In addition, Arabidopsis resistance to Leptosphaeria maculans through the RLM $1_{\text {col }}$ pathway and to Pythium irregulare was shown to be partly mediated by ABAdependent callose formation, next to callose-independent ABA-dependent resistance mechanisms (Adie et al. 2007; Kaliff et al. 2007). ABA treatment in barley also caused papillae-mediated resistance against Blumeria graminis f. sp. hordei (Wiese et al. 2004). In the interaction of tomato with Botrytis cinerea, callose deposition was low in the ABA-deficient sitiens mutant and was not important for its resistant response. However, ABA-dependent callose formation was involved in basal defense of wild-type tomato (Asselbergh and Höfte 2008). It was hypothesized that basal ABA levels in tomato are sufficiently high to create a primed state for callose deposition whereas, in Arabidopsis, which contains approximately 20fold less ABA than tomato, exogenous ABA (or BABA) is needed to provoke priming for callose deposition (Asselbergh and Höfte 2008). Furthermore, it seems that, compared with the levels of tomato resistance caused by strong SA-dependent responses (resulting from ABA-deficiency) and the strong effects of ABA-induced priming for callose in Arabidopsis, ABA-dependent callose formation only marginally influences resistance in tomato (Asselbergh and Höfte 2008).

In contrast to these reports, a negative effect of ABA on callose deposition was shown in Arabidopsis challenged with Pseudomonas syringae pv. tomato (de Torres-Zabala et al. 2007). ABA-hypersensitivity (in abil-sup7 and abil-sup5 mutants) and exogenous ABA treatment strongly reduced callose deposition, while ABA-insensitive mutants (abil-1 and abi2-1) showed augmented callose deposition (de Torres-Zabala et al. 2007).

It is noteworthy that, in some cases, ABA does not directly regulate callose deposition upon pathogen attack but, rather, modulates the priming of its deposition (after BABA treatment) (Flors et al. 2005). Also, the fact that BABA treatment enhances the capacity to resist abiotic stress (Ton et al. 2005) indicates that priming for callose deposition is mediated by ABA-responsive signaling components that are common for biotic and abiotic stress responses. This view is supported by a recent study, which shows that salt stress and BABA act synergistically in tomato to induce resistance to $P$. syringae pv. tomato (Baysal et al. 2007).

The molecular mechanisms behind the modulation of callose by ABA remain to be elucidated. It was suggested that ABA could control callose deposition by regulating vesiclemediated transport of callose synthase proteins. Transcriptional activation by ABA of specific $N$-ethyl-malmeimide-sensitive fusion protein attachment protein receptors was speculated to direct callose synthase proteins to the site of pathogen attack 
(Flors et al. 2005). Alternatively, it was proposed earlier that ABA downregulates $\beta$-1,3-glucanases, which use callose as a substrate (Rezzonico et al. 1998).

\section{ABA mediates global shifts \\ in plant stress-response priority.}

$A B A$ negatively regulates disease phenotypes in a forceful manner. Although ABA can affect disease resistance both positively and negatively, ABA seems to act as a negative regulator of defense in most plant-pathogen interactions that were studied (Table 1). One common trend that is observed among the different interactions in which ABA negatively influences disease resistance is the relatively strong effects of ABA on disease phenotypes. For example, ABA pretreatment of potato slices altered the interaction with an incompatible isolate of Phytophthora infestans to obtain disease symptoms indistinguishable from a compatible interaction. Furthermore, the same ABA treatment allowed development of Cladosporium cucumerinum, normally a nonpathogen of potato (Henfling et al. 1980). In tomato, occurrence of maceration caused by $E$. chrysanthemi was strongly reduced in the ABA-deficient sitiens mutant and spreading maceration symptoms were completely absent. This drastic reduction of disease symptoms is remarkable, considering that sources of resistance to this broad-spectrum pathogen are rare (Asselbergh et al. 2008). Fast and extensive extracellular hydrogen peroxide accumulation in sitiens was shown to be essential in establishing resistance to both $E$. chrysanthemi and B. cinerea (Asselbergh et al. 2007, 2008). Interestingly, production of ROS normally is not effective against necrotrophic pathogens such as $B$. cinerea or can even facilitate necrotrophic tissue colonization (Govrin and Levine 2000). The effective arrest of $B$. cinerea by a timely hyperinduction of hydrogen peroxide-dependent defenses in sitiens illustrates the strong effect of ABA deficiency on the defensive capacity toward pathogens (Asselbergh et al. 2007). Analysis of sitiens defense activation after inoculation with $E$. chrysanthemi pathogenicity mutant strains and with E. chrysanthemi culture filtrate demonstrated that defenses are activated by E. chrysanthemi type II secreted proteins, which mainly consist of pectinases (Asselbergh et al. 2008). E. chrysanthemi pectinolytic cell wall degradation causes the release of plant cell wall oligogalacturonides, which are known and potent endogenous elicitors of plant pathogen defenses (Ridley et al. 2001). Defense activation by endogenous elicitors that are pathogen nonspecific is consistent with the broad spectrum of pathogens that is unsuccessful in efficiently infecting sitiens plants (Asselbergh et al. 2008). These observations indicate that ABA has the capacity to negatively affect a broad range of plant-pathogen interactions in an extreme and forceful manner.

$A B A$ acts as a virulence factor of plant pathogens. The potency of ABA to suppress pathogen defense responses is exemplified by the exploitation of $\mathrm{ABA}$ as a virulence factor by plant pathogens. A recent study elegantly demonstrated that Pseudomonas syringae type III-secreted effectors (T3SE) target the Arabidopsis ABA signaling pathway to cause disease (de Torres-Zabala et al. 2007). Exogenous ABA decreases resistance in this interaction and, in addition, ABA insensitivity (in abil.1 and abi2.1 mutants) or hypersensitivity (in abil.sup7 and abi2.sup5 mutants) led to restriction or enhanced bacterial multiplication, respectively. Comparison of the Arabidopsis transcriptome after infection with wild-type and T3SE-negative $P$. syringae mutants revealed the overrepresentation of ABA-dependent gene expression in response to T3SE. The induction of ABA signaling by T3SE was represented by the upregulation of known ABA-responsive genes, by the presence of ABA-responsive elements (ABRE) in the promoter regions of T3SE-induced genes, and by the similarity between the transcriptomic profiles after T3SE-induction and ABA treatment. The upregulation of the ABA biosynthetic gene NCED3 revealed the stimulation of ABA biosynthesis by T3SE, which was confirmed by ABA measurements. Finally, transgenic expression of the conserved $P$. syringae effector AvrPtoB induced NCED3 expression and elevated ABA levels in planta (de Torres-Zabala et al. 2007). These findings demonstrate that bacterial effector-mediated elevation of plant ABA biosynthesis and signaling is a major virulence strategy, which leads to the suppression of defense responses.

In addition to regulating plant $\mathrm{ABA}$ biosynthesis, microorganisms are known to synthesize ABA themselves. ABA is produced by different types of fungi, including ascomycetes, basidiomycetes, and zygomycetes (Crocoll et al. 1991, Dörffling et al. 1984). To our knowledge, all fungal ABA-producing strains isolated so far are associated with plants. ABA biosynthesis in fungi differs from plant biosynthesis and is mediated through a direct pathway via farnesyl diphosphate (Hirai et al. 2000). The fungal ABA biosynthetic pathway is biochemically best characterized in Cercospora spp. (Oritani and Kiyota 2003) and in B. cinerea (Siewers et al. 2006). Recently, it was found that ABA biosynthetic genes in $B$. cinerea are organized in a gene cluster consisting of at least four coregulated genes (Siewers et al. 2006). Kettner and Dörffling (1995) demonstrated earlier that elevated tomato ABA levels during $B$. cinerea tissue colonization resulted from fungal stimulation of plant ABA biosynthesis and fungal inhibition of plant ABA catabolism, as well as from production of ABA and its precursor by the fungus. These findings, together with the capacity of phytopathogenic fungi from taxonomically unrelated groups to produce $\mathrm{ABA}$, indicate that elevation of host ABA levels can function as a general pathogenic strategy to suppress host defenses. Assessment of the pathogenicity of ABA- and ABA-precursor-negative fungal mutants, such as those described by Siewers and associates (2006), could further elucidate the function of ABA in pathogen virulence.

Relevant information regarding a suppressive role of ABA on plant defense possibly also can be derived from the interactions of plant roots with arbuscular mycorrhizal (AM) fungi and nitrogen-fixating bacteria because, in these symbiotic interactions, plant defense responses are suppressed (GarcíaGarrido and Ocampo 2002) and alterations in plant hormone homeostasis were reported, including increases in ABA content (Esch et al. 1994; Meixner et al. 2005). A direct link between ABA and successful AM colonization was recently provided in the tomato-Glomus intraradices interaction (HerreraMedina et al. 2007). Colonization of the ABA-deficient sitiens mutant was less frequent and arbuscule development was incomplete. In contrast, application of exogenous ABA increased AM colonization in wild-type and mutant plants. The authors suggested that impairment of AM development in ABA-deficient mutants was at least partly attributable to the antagonistic interaction of ABA with ET (Herrera-Medina et al. 2007).

ABA levels mediate a global shift in the priority of response to biotic and abiotic stress. When responding to different stresses, integration and concordance of stress-signaling networks is essential for an adequate response of appropriate amplitude, and different types of stress require distinct and specific responses. The need to prioritize specific stress responses coupled with simultaneous downregulation of others justifies the antagonistic interplay commonly observed between different stress-signaling networks. In nature, the co-occurrence of drought stress and pathogen attack is rare, because the great majority of pathogens require relatively humid conditions for infection and the establishment of disease (Agrios 2005). Furthermore, drought or dehydration stress forms a much greater threat to plant survival than pathogen infection, which is con- 
sistent with the plant's need to be able to quickly prioritize drought stress responses at the expense of growth and the responses to other stresses. ABA-responsive signaling functions as a global switch to activate the drought stress response and represses many other plant processes, among those the response to pathogens. This is consistent with ABA repressing both JA/ET-controlled and SA-controlled pathogen defense and increasing susceptibility to both necrotrophic and biotrophic pathogens. The dominant nature of ABA action also was confirmed by Anderson and associates (2004), who showed that JA/ET-dependent defense gene suppression by ABA cannot be reversed by JA or ET application. The strong antagonistic effect between abiotic and pathogen responses also is exemplified in the ABA-deficient sitiens tomato mutant. When grown under conditions of high relative humidity, ABA deficiency does not result in major morphological abnormalities. Nevertheless, ABA-deficient plants are unable to cope with drought or cold stress due to the lack of ABA-mediated stomatal regulation (Nagel et al. 1994). However, the ability of ABA-deficient tomato to block the necrotrophic pathogens $B$. cinerea and $E$. chrysanthemi reveals its enormous defensive capacity toward biotic stress (Asselbergh et al. 2007, 2008). This also was reflected at the transcriptome level, because $\mathrm{si}$ tiens exhibits higher expression of defense-related genes prior to infection and shows a further elevation quickly after $B$. cinerea inoculation (Asselbergh et al. 2007). This demonstrates that deficiency in ABA results in a global shift toward strong pathogen defense responses at the expense of reduced tolerance to abiotic stress. Taken together with the strong negative effects of $\mathrm{ABA}$ on disease phenotypes and the function of $\mathrm{ABA}$ as a virulence factor against the central role of $\mathrm{ABA}$ in abiotic stress responses, it seems that, in general, strong decreases in ABA levels lead to hyperactivation of pathogen defense together with a reduced capacity to react to abiotic stress, whereas elevation of ABA levels leads to enhanced abiotic stress responses and suppression of pathogen defense responses.

\section{ABA integrates and fine-tunes different stress responses.}

Overlap between abiotic and biotic stress responses. In addition to the apparent role of ABA levels in mediating a global shift between abiotic and biotic stress responses, ABA-responsive signaling seems to interfere at multiple steps in various signal transduction cascades, leading to fine-tuning and integration of different stress responses. Economical use of biochemical resources implies a significant amount of overlap between the responses to different stresses and explains the use of common signaling components in the response to both biotic and abiotic stresses. Furthermore, biotic and abiotic stress responses can show considerable overlap at the level of signal perception. For example, root rot or wilting pathogens can cause dehydration stress and, thereby, trigger an abiotic stress response. As a result, the influence of $\mathrm{ABA}$ on disease signaling is extremely divergent and disease resistance can be positively or negatively affected by ABA. An overview of ABA action on pathogen defense responses described in this article is given in Figure 1. Additional points of convergence between the signaling responses to abiotic and biotic stress have been characterized (Fujita et al. 2006; Mauch-Mani and Mauch

\section{BIOTICIABIOTIC STRESS PERCEPTION}

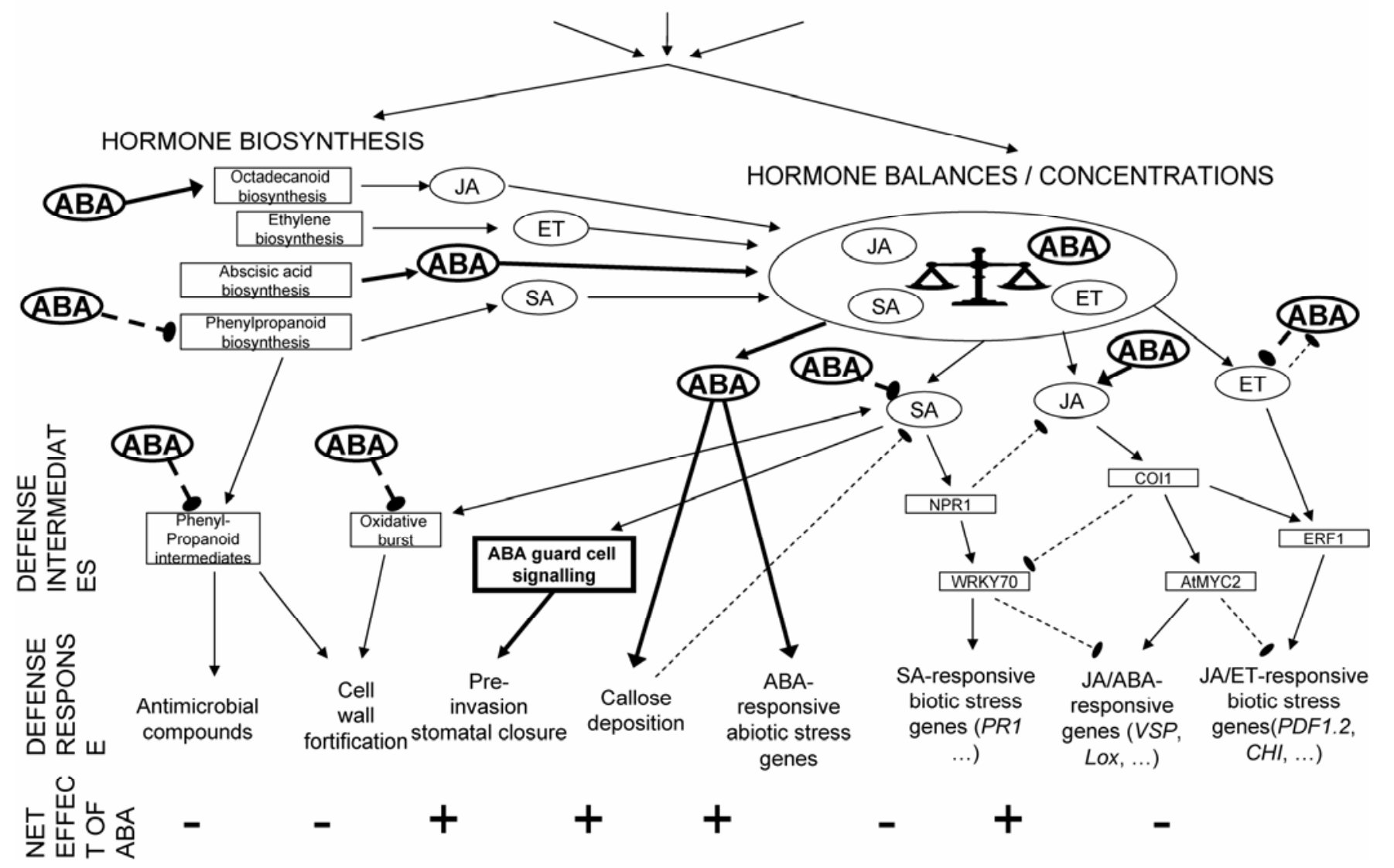

Fig. 1. Schematic representation of abscisic acid (ABA) interfering with plant abiotic and biotic stress responses. Emphasis is given to ABA influencing pathogen defense responses via different modes of action and not to the functions of ABA signaling in abiotic stress responses. The representation of jasmonate (JA), ethylene (ET), and salicylic acid (SA) cross-talk involving the transcription factors AtMYC2, NPR1, COI1, ERF1, and WRKY70 was based partly on a model by Lorenzo and Solano (2005). Sharp full-line arrows represent stimulatory effects and blunt dotted-line arrows represent repressive effects. Effects of ABA are marked in bold. 
2005). However, it seems that only a tiny portion of the total overlap of abiotic and biotic stress signaling networks has been described. Several signaling mechanisms of high complexity are shared between ABA abiotic stress signaling and pathogen defense and constitute means of overlap between different pathways, including $\mathrm{Ca}^{2+}$ and Ca-dependent protein kinase signaling (Klüsener et al. 2002; Ludwig et al. 2004), ROS and nitric oxide signaling (Apel and Hirt 2004; Pastori and Foyer 2002), mitogen-activated protein kinase signaling cascades (Fujita et al. 2006; Xiong and Yang 2003), and various transcription factor families, containing functional domains such as AP2, WRKY, bZIP/HD-ZIP, MYB, MYC, and several classes of zinc fingers (Anderson et al. 2004; Chen et al. 2002; Li et al. 2004; Mengiste et al. 2003; Zhu et al. 2005). The number of reports that functionally characterize transcription factors and signaling components involved in both biotic and abiotic stresses is growing fast and originates from studies on various plant species. For example, the pepper $\mathrm{C} 3-\mathrm{H}-\mathrm{C} 4$ type RING-finger protein CaRFP1 functions as an early defense regulator controlling disease susceptibility and osmotic stress tolerance, probably by influencing SA and ABA signaling, respectively (Hong et al. 2007). Also, the barley ERF-type transcription factor HvRAF enhances pathogen resistance and salt tolerance (Jung et al. 2007). Ectopic expression of HvRAF in Arabidopsis confers its conserved function. Similarly, ectopic expression of the rice Osmyb4 upstream transcription factor in Arabidopsis was shown to have a positive effect on the responses to abiotic (cold, drought, and salt), environmental (ozone and UV), and biotic (Tobacco necrosis virus, B. cinerea, P. syringae) stresses (Vannini et al. 2006). However, overexpression of the same gene in tomato only improved tolerance to drought stress and virus infection while other stress responses were not improved (Vannini et al. 2007), demonstrating that the conservation of stress-response machinery in dicotyledonous plants is only partial. Further unraveling of the components regulating the signaling events between different stress stimuli and their resulting defense measures will contribute to understanding the integration of overlapping stress signaling networks and the complex role of ABA herein. Even greater challenges presumably will lie in combining information from different plant species on partially conserved stressresponse-signaling networks and transferring this knowledge to applied agricultural benefits.

Complexity of ABA-mediated responses. The process of establishing and interpreting possible functions of ABA in plants is hindered by the complexity of ABA-mediated responses. ABA-dependent responses are regulated by controlling de novo ABA synthesis. The first steps of ABA biosynthesis occur in chloroplasts where cleavage of caretenoids by nine-cis epoxycaretenoid dioxygenases (NCED) is the rate-limiting step and transcriptional regulation of the NCED is the major control point of ABA biosynthesis. In addition, the level of ABA in plants is controlled not only by its synthesis but also through its catabolism (Schwartz et al. 2003). However, ABAregulated processes constitute more than a simple response to in planta bulk ABA concentrations (Wilkinson and Davies 2002). During drought stress, instant stomatal closure is essential for the plants' survival and is mediated by ABA perception at the guard cells. Whereas severe drought stress that causes water deficit in the shoot is followed by a drastic increase in levels of intracellular leaf ABA, drought stress that is perceived only at the roots specifically increases apoplastic ABA in guard cells without influencing symplastic leaf ABA contents or leaf bulk apoplastic ABA (Wilkinson and Davies 2002). This not only implicates the existence of ABA perception sites at different locations and the co-regulation of chemical and hydraulic signals but also implies a whole-plant modulation of the ABA signal, including differential xylem loading in the roots, $\mathrm{ABA}$ sequestration into a symplastic leave reservoir, and alteration of guard cell sensitivity to ABA (Wilkinson and Davies 2002). In addition, drought-stress-induced ABA can stimulate primary root elongation while shoot growth decreases, leading to increased water absorption and reduced water loss, respectively (Sharp 2002). These and other findings indicate that, even during a single stress response, different signaling mechanisms are required that can be stage, organ, or cell specific.

One mechanism that can help to explain the diversity in $\mathrm{ABA}$ responses is the existence of different ABA receptors. Indeed, over the last few years, different research groups have characterized three proteins that each fulfill the biochemical requirements of an ABA receptor (stereospecific and saturable high-affinity binding to one binding site). An Arabidopsis nuclear protein, flowering control protein $\mathrm{A}$, is an RNA-binding protein and is required for ABA signaling in controlling flowering and lateral root formation but not in seed germination or the stomatal response (Razem et al. 2006). The Arabidopsis protein ABAR/CHLH (putative ABA receptor/Mg-chelatase $\mathrm{H}$ subunit) specifically binds $\mathrm{ABA}$ in chloroplasts, functions at the whole plant level, and controls seed germination and stomatal movement (Shen et al. 2006). Finally, ABA perception at the cell surface was reported to be mediated by a G-protein coupled receptor (Liu et al. 2007); however, its function in ABA responses still needs to be unambiguously demonstrated (Gao et al. 2007).

Downstream of ABA perception, the components of the complex signaling network include RNA-binding proteins (Hugouvieux et al. 2001), protein kinases (Osakabe et al. 2005), protein phosphatases (Leung et al. 1997), and multipletype transcription factors (Finkelstein and Rock 2002). In addition, a recent transcriptomic analysis that used ABA structural analogs to detect genes that are weakly induced by ABA estimated that approximately 14\% of Arabidopsis genes are ABA regulated (Huang et al. 2007). Furthermore, comparison of the ABA-regulated genes that were identified in other studies (Hoth et al. 2002; Leonardt et al. 2004; Seki et al. 2001) suggests that the full potential of ABA-responsive gene regulation has not yet been identified (Huang et al. 2007). Taken together, our understanding of ABA perception, ABA-signaling networks, and whole-plant ABA-mediated plant responses is still very fragmentary and incomplete. Further elucidation of the particularly complex mechanisms of responses to ABA will help to clarify many important plant processes in which ABA is involved, including the response to pathogens.

\section{Conclusions.}

The modulation of disease resistance by ABA is a particularly complex phenomenon and our knowledge of the diverse regulatory effects of $\mathrm{ABA}$ on defense responses currently fails to provide us with straightforward interpretations or clear-cut models on how ABA affects disease resistance. ABA seems to have divergent effects on defense responses, and the outcome on disease resistance seems to be plant-pathogen interaction specific, rather than to depend on the plant species or the lifestyle of the pathogen that is involved (Table 1). Moreover, even within the same plant pathosystem, ABA can have divergent effects depending on the timing of infection, as was shown in the Arabidopsis-P. syringae interaction.

One function of ABA in plant-pathogen interactions can be obtained from the capacity of plant ABA levels to control a global shift between the response to abiotic and biotic stress. During abiotic stresses such as drought stress, to which the plant's response is more crucial for survival compared with biotic stress, plant ABA levels rise, which results in a priority to 
confer abiotic stress tolerance and a decrease in capacity to resist pathogens. This view is consistent with the function of ABA as a virulence factor of plant pathogens (de TorresZabala et al. 2007), with the dominant nature of ABA to suppress JA/ET- or SA-controlled pathogen defense responses (Anderson et al. 2004, Audenaert et al. 2002), and with the strong effects on disease phenotypes characterized by the apparently complete abolishment of defense (Henfling et al. 1980). Conversely, ABA deficiency, which results in a decreased tolerance to abiotic stresses, can result in an extremely high capacity to resist pathogen infection (Asselbergh et al. 2007, 2008).

In addition to the ABA-controlled global switch in response priority toward biotic or abiotic stress, ABA greatly influences the large and complex overlap between abiotic and biotic stress-signaling pathways at multiple levels, resulting in both positive and negative regulation of defense to pathogens. Our current knowledge only covers small fragments of these signaling pathways, and the unraveling of the multiplex role of ABA herein is further complicated by the complexity of ABAmediated signaling responses in general. However, the fastgrowing number of reports that deal with ABA regulating pathogen defense responses should further establish and illuminate the function of ABA as a key player in plant biotic stress responses.

\section{ACKNOWLEDGMENTS}

This work was supported by a specialization fellowship of the Flemish institute for the stimulation of Scientific-Technological Research in Industry (IWT, Belgium) given to D. De Vleesschauwer, the "Fonds voor Wetenschappelijk onderzoek-Vlaanderen" (grants no. G.0350.04 and G.0061.03), and the Special Research Fund ("Bijzonder Onderzoeksfonds") of Ghent University.

\section{LITERATURE CITED}

Achuo, E. A., Prinsen, E., and Höfte, M. 2006. Influence of drought, salt stress and abscisic acid on the resistance of tomato to Botrytis cinerea and Oidium neolycopersici. Plant Pathol. 55:178-186.

Adie, B. A. T., Perez-Perez, J., Perez-Perez, M. M., Godoy, M., SanchezSerrano, J. J., Schmelz, E. A., and Solano, R. 2007. ABA is an essential signal for plant resistance to pathogens affecting JA biosynthesis and the activation of defenses in Arabidopsis. Plant Cell 19:1665-1681.

Agrios, G. N. 2005. Plant Pathology, 4th ed. Academic Press, San Diego, CA, U.S.A.

Aist, J. R. 1976. Papillae and related wound plugs of plant cells. Annu. Rev. Phytopathol. 14:145-163.

Alvarez, M. E., Pennell, R. I., Meijer, P. J., Ishikawa, A., Dixon, R. A., and Lamb, C. 1998. Reactive oxygen intermediates mediate a systemic signal network in the establishment of plant immunity. Cell 92:773-784.

Anderson, J. P., Badruzsaufari, E., Schenk, P. M., Manners, J. M., Desmond, O. J., Ehlert, C., Maclean, D. J., Ebert, P. R., and Kazan, K. 2004. Antagonistic interaction between abscisic acid and jasmonate-ethylene signaling pathways modulates defense gene expression and disease resistance in Arabidopsis. Plant Cell 16:3460-3479.

Apel, K., and Hirt., H. 2004. Reactive oxygen species: metabolism, oxidative stress, and signal transduction. Annu. Rev. Plant Biol. 55:373-399.

Asselbergh, B., and Höfte, M. 2008. Basal tomato defenses to Botrytis cinerea include ABA-dependant callose formation. Physiol. Mol. Plant Pathol. October, 4 2007; DOI: 10.1016/J.PMPP.2007.10.001.

Asselbergh, B., Curvers, C., França, S. C., Audenaert, K., Vuylsteke, M., Van Breusegem, F., and Höfte, M. 2007. Resistance to Botrytis cinerea in sitiens, an abscisic acid-deficient tomato mutant, involves timely production of hydrogen peroxide and cell wall modifications in the epidermis. Plant Physiol. 144:1863-1877.

Asselbergh, B., Achuo, E. A., Höfte, M., and Van Gijsegem, F. 2008. Abscisic acid-deficiency leads to rapid activation of tomato defense responses upon infection with Erwinia chrysanthemi. Mol. Plant Pathol. 9:11-24.

Audenaert, K., De Meyer, G. B., and Höfte, M. 2002. Abscisic acid determines basal susceptibility of tomato to Botrytis cinerea and suppresses salicylic acid-dependent signaling mechanisms. Plant Physiol. 128:491501
Baysal, O., Gursoy, Y. Z., Ornek, H., Cetinel, B., and da Silva, J. A. T. 2007. Enhanced systemic resistance to bacterial speck disease caused by Pseudomonas syringae pv. tomato by DL-beta-aminobutyric acid under salt stress. Physiol. Plant. 129:493-506.

Chen, W. Q., Provart, N. J., Glazebrook, J., Katagiri, F., Chang, H. S., Eulgem, T., Mauch, F., Luan, S., Zou, G. Z., Whitham, S. A. , Budworth, P. R., Tao, Y., Xie, Z. Y., Chen, X., Lam, S., Kreps, J. A., Harper, J. F., Si-Ammour, A., Mauch-Mani, B., Heinlein, M., Kobayashi, K., Hohn, T., Dangl, J. L., Wang, X., and Zhu, T. 2002. Expression profile matrix of Arabidopsis transcription factor genes suggests their putative functions in response to environmental stresses. Plant Cell 14:559-574.

Crocoll, C., Kettner, J., and Dörffling, K. 1991. Abscisic acid in saprophytic and parasitic species of fungi. Phytochemistry 30:1059-1060.

De Paepe, A., Vuylsteke, M., Van Hummelen, P., Zabeau, M., and Van Der Straeten, D. 2004. Transcriptional profiling by cDNA-AFLP and microarray analysis reveals novel insights into the early response to ethylene in Arabidopsis. Plant J. 39:537-559.

de Torres-Zabala, M., Truman, W., Bennett, M. H., Lafforgue, G. Mansfield, J. W., Egea, P. R., Bogre, L., and Grant, M. 2007. Pseudomonas syringae pv. tomato hijacks the Arabidopsis abscisic acid signaling pathway to cause disease. EMBO (Eur. Mol. Biol. Organ.) J. 26:1434-1443.

Dörffling, K., Petersen, W., Sprecher, E., Urbasch, I., and Hanssen, H. P. 1984. Abscisic acid in phytopathogenic fungi of the genera Botrytis, Ceratocystis, Fusarium, and Rhizoctonia. J. Biosci. 39:683-684.

Dunn, R. M., Hedden, P., and Bailey, J. A. 1990. A physiologically induced resistance of Phaseolus vulgaris to a compatible race of Colletotrichum lindemuthianum is associated with increases in ABA content. Physiol. Mol. Plant Pathol. 36:339-349.

Durrant, W. E., and Dong, X. 2004. Systemic acquired resistance. Annu. Rev. Phytopathol. 42:185-209.

Edwards, H. H. 1983. Effect of kinetin, abscisic acid, and cations on hostparasite relations of barley inoculated with Erysiphe graminis f. sp. hor dei. J. Phytopathol. 107:22-30.

Esch, H., Hundeshagen, B., Schneiderpoetsch, H., and Bothe, H. 1994. Demonstration of abscisic acid in spores and hyphae of the arbuscular mycorrhizal fungus Glomus and in the $\mathrm{N}_{2}$-fixing cyanobacterium Anabaena variabilis. Plant Sci. 99:9-16.

Finkelstein, R. R., and Rock, C. D. 2002. Abscisic Acid Biosynthesis and Response. In: The Arabidopsis Book. C. R. Somerville and E. M. Meyerowitz, eds. American Society of Plant Biologists, Rockville, MD. doi: 10.1199/tab.0009. Published online.

Finkelstein, R. R., Gampala, S. S. L., and Rock, C. D. 2002. Abscisic acid signaling in seeds and seedlings. Plant Cell 14:S15-S45.

Flors, V., Ton, J., Jakab, G., and Mauch-Mani, B. 2005. Abscisic acid and callose: team players in defense against pathogens? J. Phytopathol. 153: 377-383.

Fujita, M., Fujita, Y., Noutoshi, Y., Takahashi, F., Narusaka, Y., YamaguchiShinozaki, K., and Shinozaki, K. 2006. Crosstalk between abiotic and biotic stress responses: a current view from the points of convergence in the stress signaling networks. Curr. Opin. Plant Biol. 9:436-442.

Gao, Y., Zeng, Q., Guo, J., Cheng, J., Ellis, B. E., and Chen, J. G. 2007. Genetic characterization reveals no role for the reported ABA receptor, GCR2, in ABA control of seed germination and early seedling development in Arabidopsis. Plant J. 52:1001-1013.

Garcia-Garrido, J. M., and Ocampo, J. A. 2002. Regulation of the plant defense response in arbuscular mycorrhizal symbiosis. J. Exp. Bot. 53:1377-1386

Glazebrook, J. 2005. Contrasting mechanisms of defense against biotrophic and necrotrophic pathogens. Annu. Rev. Phytopathol. 43:205-227.

Govrin, E. M., and Levine, A. 2000. The hypersensitive response facilitates plant infection by the necrotrophic pathogen Botrytis cinerea. Curr. Biol. 10:751-757.

Guimarães, R. L., and Stotz, H. U. 2004. Oxalate production by Sclerotinia sclerotiorum deregulates guard cells during infection. Plant Physiol. 136:3703-3711.

Henfling, J., Bostock, R., and Kuc, J. 1980. Effect of abscisic acid on rishitin and lubimin accumulation and resistance to Phytophthora infestans and Cladosporium cucumerinum in potato tuber tissue slices. Phytopathology 70:1074-1078.

Hernández-Blanco, C., Feng, D. X., Hu, J., Sanchez-Vallet, A., Deslandes, L., Llorente, F., Berrocal-Lobo, M., Keller, H., Barlet, X., SanchezRodriguez, C., Anderson, L. K., Somerville, S., Marco, Y., and Molina, A. 2007. Impairment of cellulose synthases required for Arabidopsis secondary cell wall formation enhances disease resistance. Plant Cell 19:890-903.

Herrera-Medina, M. J., Steinkellner, S., Vierheilig, H., Bote, J. A. O., and Garrido, J. M. G. 2007. Abscisic acid determines arbuscule development and functionality in the tomato arbuscular mycorrhiza. New Phytol. 175:554-564. 
Hirai, N., Yoshida, R., Todoroki, Y., and Ohigashi, H. 2000. Biosynthesis of abscisic acid by the non-mevalonate pathway in plants, and by the mevalonate pathway in fungi. Biosci. Biotechnol. Biochem. 64:14481458.

Hong, J. K., Choi, H. W., Hwang, I. S., and Hwang, B. K. 2007. Role of a novel pathogen-induced pepper $\mathrm{C} 3-\mathrm{H}-\mathrm{C} 4$ type RING-finger protein gene, CaRFP1, in disease susceptibility and osmotic stress tolerance. Plant Mol. Biol. 63:571-588.

Hoth, S., Morgante, M., Sanchez, J. P., Hanafey, M. K., Tingey, S. V., and Chua, N. H. 2002. Genome-wide gene expression profiling in Arabidopsis thaliana reveals new targets of abscisic acid and largely impaired gene regulation in the abil-1 mutant. J. Cell Sci. 115:4891-4900.

Huang, D. Q., Jaradat, M. R., Wu, W. R., Ambrose, S. J., Ross, A. R., Abrams, S. R., and Cutler, A. J. 2007. Structural analogs of ABA reveal novel features of ABA perception and signaling in Arabidopsis. Plant J. 50:414-428

Hugouvieux, V., Kwak, J. M., and Schroeder, J. I. 2001. An mRNA cap binding protein, $\mathrm{ABH} 1$, modulates early abscisic acid signal transduction in Arabidopsis. Cell 106:477-487.

Jung, J., Won, S. Y., Suh, S. C., Kim, H., Wing, R., Jeong, Y., Hwang, I., and Kim, M. 2007. The barley ERF-type transcription factor HvRAF confers enhanced pathogen resistance and salt tolerance in Arabidopsis. Planta 225:575-588

Kaliff, M., Staal, J., Myrenas, M., and Dixelius, C. 2007. ABA is required for Leptosphaeria maculans resistance via ABI1- and ABI4-dependent signaling. Mol. Plant-Microbe Interact. 20:335-345.

Kettner, J., and Dörffling, K. 1995. Biosynthesis and metabolism of abscisic acid in tomato leaves infected with Botrytis cinerea. Planta 196:627-634

Klüsener, B., Young, J. J., Murata, Y., Allen, G. J., Mori, I. C., Hugouvieux, V., and Schroeder, J. I. 2002 Convergence of calcium signaling pathways of pathogenic elicitors and abscisic acid in Arabidopsis guard cells. Plant Physiol. 130:2152-2163.

Koga, H., Dohi, K., and Mori, M. 2004. Abscisic acid and low temperatures suppress the whole plant-specific resistance reaction of rice plants to the infection of Magnaporthe grisea. Physiol. Mol. Plant Pathol. 65:3-9.

Kwak, J. M., Nguyen, V., and Schroeder, J. I. 2006. The role of reactive oxygen species in hormonal responses. Plant Physiol. 141:323-329.

Lamb, C., and Dixon, R. A. 1997. The oxidative burst in plant disease resistance. Annu. Rev. Plant Physiol. Plant Mol. Biol. 48:251-275.

Lee, S., Choi, H., Suh, S., Doo, I. S., Oh, K. Y., Choi, E. J., Taylor, A. T. S., Low, P. S., and Lee, Y. 1999. Oligogalacturonic acid and chitosan reduce stomatal aperture by inducing the evolution of reactive oxygen species from guard cells of tomato and Commelina communis. Plant Physiol. 121:147-152.

Leonhardt, N., Kwak, J. M., Robert, N., Waner, D., Leonhardt, G., and Schroeder, J. I. 2004. Microarray expression analyses of Arabidopsis guard cells and isolation of a recessive abscisic acid hypersensitive protein phosphatase 2C mutant. Plant Cell 16:596-615.

Leung, J., Merlot, S., and Giraudat, J. 1997 The Arabidopsis ABSCISIC $A C I D$-INSENSITIVE2 (ABI2) and ABII genes encode homologous protein phosphatases $2 \mathrm{C}$ involved in abscisic acid signal transduction. Plant Cell 9:759-771.

Li, J., Brader, G., and Palva, E. T. 2004. The WRKY70 transcription factor: A node of convergence for jasmonate-mediated and salicylate-mediated signals in plant defense. Plant Cell 16:319-331.

Li, S., Assmann, S. M., and Albert, R. 2006. Predicting essential components of signal transduction networks: A dynamic model of guard cell abscisic acid signaling. Plos Biol. 4:1732-1748.

Liu, X. G., Yue, Y. L., Li, B., Nie, Y. L., Li, W., Wu, W. H., and Ma, L. G. 2007. A G protein-coupled receptor is a plasma membrane receptor for the plant hormone abscisic acid. Science 315:1712-1716.

Lorenzo, O., and Solano, R. 2005. Molecular players regulating the jasmonate signaling network. Curr. Opin. Plant Biol. 8:532-540.

Lorenzo, O., Chico, J. M., Sanchez-Serrano, J. J., and Solano, R. 2004 Jasmonate-insensitive 1 encodes a MYC transcription factor essential to discriminate between different jasmonate-regulated defense responses in Arabidopsis. Plant Cell 16:1938-1950.

Ludwig, A. A., Romeis, T., and Jones, J. D. G. 2004. CDPK-mediated signaling pathways: specificity and cross-talk. J. Exp. Bot. 55:181-188.

Marré, E. 1979. Fusicoccin-tool in plant physiology. Annu. Rev. Plant Physiol. Plant Mol. Biol. 30:273-288.

Mauch-Mani, B., and Mauch, F. 2005. The role of abscisic acid in plantpathogen interactions. Curr. Opin. Plant Biol. 8:409-414.

McDonald, K. L., and Cahill, D. M. 1999 Influence of abscisic acid and the abscisic acid biosynthesis inhibitor, norflurazon, on interactions between Phytophthora sojae and soybean (Glycine max). Eur. J. Plant Pathol. 105:651-658.

Meixner, C., Ludwig-Muller, J., Miersch, O., Gresshoff, P., Staehelin, C., and Vierheilig, H. 2005. Lack of mycorrhizal autoregulation and phyto- hormonal changes in the supernodulating soybean mutant nts1007. Planta 222:709-715.

Melotto, M., Underwood, W., Koczan, J., Nomura, K., and He, S. Y. 2006 Plant stomata function in innate immunity against bacterial invasion. Cell 126:969-980.

Mengiste, T., Chen, X., Salmeron, J., and Dietrich, R. 2003. The BOTRY TIS SUSCEPTIBLE1 gene encodes an R2R3MYB transcription factor protein that is required for biotic and abiotic stress responses in Arabidopsis. Plant Cell 15:2551-2565.

Mohr, P. G., and Cahill, D. M. 2001. Relative roles of glyceollin, lignin and the hypersensitive response and the influence of ABA in compatible and incompatible interactions of soybeans with Phytophthora sojae. Physiol. Mol. Plant Pathol. 58:31-41.

Mohr, P. G., and Cahill, D. M. 2003. Abscisic acid influences the susceptibility of Arabidopsis thaliana to Pseudomonas syringae pv. tomato and Peronospora parasitica. Funct. Plant Biol. 30:461-469.

Mohr, P. G., and Cahill, D. M. 2007. Suppression by ABA of salicylic acid and lignin accumulation and the expression of multiple genes, in Arabidopsis infected with Pseudomonas syringae pv. tomato. Funct. Integr. Genomics 7:181-191.

Moons, A., Prinsen, E., Bauw, G., and Van Montagu, M. 1997. Antagonistic effects of abscisic acid and jasmonates on salt stress-inducible transcripts in rice roots. Plant Cell 9:2243-2259.

Munemasa, S., Oda, K., Watanabe-Sugimoto, M., Nakamura, Y., Shimoishi, Y., and Murata, Y. 2007 The coronatine-insensitive 1 mutation reveals the hormonal signaling interaction between abscisic acid and methyl jasmonate in Arabidopsis guard cells. Specific impairment of ion channel activation and second messenger production. Plant Physiol. 143:1398-1407.

Nagel, O. W., Konings, H., and Lambers, H. 1994. Growth rate, plant development and water relations of the ABA-deficient tomato mutant $\mathrm{Si}$ tiens. Physiol. Plant. 92:102-108.

Nikitina, A. V., and Talieva, M. N. 2001. Endogenous abscisic acid in wheat plants upon inoculation with the powdery mildew causative agent (Erysiphe graminis f. sp tritici). Biol. Bull. 28:262-265.

Nishimura, M. T., Stein, M., Hou, B. H., Vogel, J. P., Edwards, H., and Somerville, S. C. 2003 Loss of a callose synthase results in salicylic acid-dependent disease resistance. Science 301:969-972.

Oritani, T., and Kiyota, H. 2003. Biosynthesis and metabolism of abscisic acid and related compounds. Nat. Prod. Rep. 20:414-425.

Osakabe, Y., Maruyama, K., Seki, M., Satou, M., Shinozaki, K., and Yamaguchi-Shinozaki, K. 2005. Leucine-rich repeat receptor-like kinase 1 is a key membrane-bound regulator of abscisic acid early signaling in Arabidopsis. Plant Cell 17:1105-1119.

Pastori, G. M., and Foyer, C. H. 2002. Common components, networks, and pathways of cross-tolerance to stress. The central role of "redox" and abscisic acid-mediated controls. Plant Physiol. 129:460-468.

Razem, F. A., El-Kereamy, A., Abrams, S. R., and Hill, R. D. 2006. The RNA-binding protein FCA is an abscisic acid receptor. Nature 439:290294.

Rezzonico, E., Flury, N., Meins, F., and Beffa, R. 1998. Transcriptional down-regulation by abscisic acid of pathogenesis-related beta-1,3-glucanase genes in tobacco cell cultures. Plant Physiol. 117:585-592.

Ridley, B. L., O’Neill, M. A., and Mohnen, D. A. 2001. Pectins: structure, biosynthesis, and oligogalacturonide-related signaling. Phytochemistry 57:929-967.

Salt, S. D., Tuzun, S., and Kuc, J. 1986. Effects of beta-ionone and abscisic acid on the growth of tobacco and resistance to blue mold-mimicry of effects of stem infection by Peronospora tabacina Adam. Physiol. Mol. Plant Pathol. 28:287-297.

Schwartz, S. H., Qin, X. Q., and Zeevaart, J. A. D. 2003. Elucidation of the indirect pathway of abscisic acid biosynthesis by mutants, genes, and enzymes. Plant Physiol. 131:1591-1601.

Seki, M., Narusaka, M., Abe, H., Kasuga, M., Yamaguchi-Shinozaki, K., Carninci, P., Hayashizaki, Y., and Shinozaki, K. 2001. Monitoring the expression pattern of 1300 Arabidopsis genes under drought and cold stresses by using a full-length cDNA microarray. Plant Cell 13:61-72.

Sharp, R. E. 2002. Interaction with ethylene: changing views on the role of abscisic acid in root and shoot growth responses to water stress. Plant Cell Environ. 25:211-222.

Shen, Y. Y., Wang, X. F., Wu, F. Q., Du, S. Y., Cao, Z., Shang, Y., Wang, X. L., Peng, C. C., Yu, X. C., Zhu, S. Y., Fan, R. C., Xu, Y. H., and Zhang, D. P. 2006. The $\mathrm{Mg}$-chelatase $\mathrm{H}$ subunit is an abscisic acid receptor Nature 443:823-826.

Siewers, V., Kokkelink, L., Smedsgaard, J., and Tudzynski, P. 2006. Identification of an abscisic acid gene cluster in the grey mold Botrytis cinerea. Appl. Environ. Microbiol. 72:4619-4626.

Thaler, J. S., and Bostock, R. M. 2004. Interactions between abscisic-acidmediated responses and plant resistance to pathogens and insects. Ecology $85: 48-58$. 
Thomma, B., Penninckx, I., Broekaert, W. F., and Cammue, B. P. A. 2001. The complexity of disease signaling in Arabidopsis. Curr. Opin. Immunol. 13:63-68.

Ton, J., and Mauch-Mani, B. 2004. Beta-amino-butyric acid-induced resistance against necrotrophic pathogens is based on ABA-dependent priming for callose. Plant J. 38:119-130.

Ton, J., Jakab, G., Toquin, V., Flors, V., Iavicoli, A., Maeder, M. N., Metraux, J. P., and Mauch-Mani, B. 2005. Dissecting the beta-aminobutyric acid-induced priming phenomenon in Arabidopsis. Plant Cell 17:987-999.

Torres, M. A., and Dangl, J. L. 2005. Functions of the respiratory burst oxidase in biotic interactions, abiotic stress and development. Curr. Opin. Plant Biol. 8:397-403.

Underwood, W., Melotto, M., and He, S. Y. 2007. Role of plant stomata in bacterial invasion. Cell. Microbiol. 9:1621-1629.

Van Breusegem, F., Vranova, E., Dat, J. F., and Inzé, D. 2001. The role of active oxygen species in plant signal transduction. Plant Sci. 161:405414.

Van Camp, W., Van Montagu, M., and Inzé, D. 1998. $\mathrm{H}_{2} \mathrm{O}_{2}$ and NO: redox signals in disease resistance. Trends Plant Sci. 3:330-334.

van Kan, J. A. L. 2006. Licensed to kill: the lifestyle of a necrotrophic plant pathogen. Trends Plant Sci. 11:247-253.

van Loon, L. C., Geraats, B. P. J., and Linthorst, H. J. M. 2006. Ethylene as a modulator of disease resistance in plants. Trends Plant Sci. 11:184-191.

Vannini, C., Iriti, M., Bracale, M., Locatelli, F., Faoro, F., Croce, P., Pirona, R., Di Maro, A., Coraggio, I., and Genga, A. 2006. The ectopic expression of the rice Osmyb4 gene in Arabidopsis increases tolerance to abiotic, environmental and biotic stresses. Physiol. Mol. Plant Pathol. 69:26-42.
Vannini, C., Campa, M, Iriti, M., Genga, A., Faoro, F., Carravieri, S Rotino, G. L., Rossoni, M., Spinardi, A., and Bracale, M. 2007. Evaluation of transgenic tomato plants ectopically expressing the rice Osmyb4 gene. Plant Sci. 173:231-239.

Ward, E. W. B., Cahill, D. M., and Bhattacharyya, M. K. 1989. Abscisic acid suppression of phenylalanine ammonia lyase activity and messenger RNA, and resistance of soybeans to Phytophthora megasperma f. sp. glycinea. Plant Physiol. 91:23-27.

Wiese, J., Kranz, T., and Schubert, S. 2004. Induction of pathogen resistance in barley by abiotic stress. Plant Biol. 6:529-536

Wilkinson, S., and Davies, W. J. 2002. ABA-based chemical signaling: the co-ordination of responses to stress in plants. Plant Cell Environ. 25:195-210.

Wojtaszek, P. 1997. Oxidative burst: an early plant response to pathogen infection. Biochem. J. 322:681-692.

Xiong, L. Z., and Yang, Y. N. 2003. Disease resistance and abiotic stress tolerance in rice are inversely modulated by an abscisic acid-inducible mitogen-activated protein kinase. Plant Cell 15:745-759.

Yang, Y. 2007. Towards understanding of signal perception and transduction in rice blast resistance. The 4th International Rice Blast Conference, Changsha, China.

Yang, Z., Tian, L., Latoszek-Green, M., Brown, D., and Wu, K. 2005. Arabidopsis ERF4 is a transcriptional repressor capable of modulating ethylene and abscisic acid responses. Plant Mol. Biol. 58:585-596.

Zhu, J. H., Verslues, P. E., Zheng, X. W., Lee, B., Zhan, X. Q., Manabe, Y., Sokolchik, I., Zhu, Y. M., Dong, C. H., Zhu, J. K., Hasegawa, P. M., and Bressan, R. A. 2005. HOS10 encodes an R2R3-type MYB transcription factor essential for cold acclimation in plants. Proc. Natl. Acad. Sci. U.S.A. 102:9966-9971. 